\title{
Isolation of Lipase-Producing Yeasts from Industrial Oily Residues in Different Culture Media
}

\author{
Michele Putti Paludo ${ }^{1}$, Kelly Silva Degani de Oliveira², \\ Thalles Canton Trevisol ${ }^{2}$ and Janaina Fernandes de Medeiros Burkert ${ }^{2 *}$
}

\author{
${ }^{1}$ Federal University of Rio Grande (FURG), Chemistry and Food School (EQA), Campus \\ Carreiros: Avenida Itália km 8 Bairro Carreiros, Rio Grande, Brazil \\ ${ }^{2}$ Federal University of Rio Grande (FURG), Chemistry and Food School (EQA), \\ Rio Grande, Brazil
}

*Corresponding author

\section{A B S T R A C T}

\section{Keywords \\ Esterification activity, Factorial design, \\ Screening, Lipolytic yeast, Yarrowia lipolytica}

\section{Article Info}

Accepted:

16 December 2017

Available Online:

10 January 2018
The main goal of this work was to collect industrial oily residues and isolate lipolytic yeasts by selecting the best strain in relation to lipolytic and esterification activities and investigate the increase of production in shake flasks. A total of 78 yeasts were isolated on Yeast Malt agar and 44 strains with lipase-producing potential pre-selected on tributyrin agar. The yeast identified as Yarrowia lipolytica showed the highest lipolytic and esterification activities, reaching $2.67 \mathrm{U} / \mathrm{mL}$ and $464.65 \mathrm{U} / \mathrm{g}$, respectively, at $48 \mathrm{~h}$. Medium 4 showed major lipolytic $(2.23 \mathrm{U} / \mathrm{mL})$ and esterification $(324.98 \mathrm{U} / \mathrm{g})$ activity, concomitantly. The components of this medium were used in the factorial design; it was observed that an increase in the concentration of $\mathrm{MgSO}_{4}$ and olive oil decreased lipolytic activity significantly $(\mathrm{p}<0.05)$, and the other variables did not influence lipase production. The esterification activity and cell concentration were not affected significantly $(\mathrm{p}>0.05)$ for any of the variables studied. An increase in lipolytic activity was reached in trial 9 $(5.12 \mathrm{U} / \mathrm{mL})$ and trial $1(5.23 \mathrm{U} / \mathrm{mL})$ and the maximum esterification activity was 133.19 $\mathrm{U} / \mathrm{g}$ (trial 14). Additionally, the trial 15 showed relevant activities $(4.32 \mathrm{U} / \mathrm{mL}$ and 105.22 $\mathrm{U} / \mathrm{g})$ beyond the cell concentration $(10.30 \mathrm{~g} / \mathrm{L})$, obtained concomitantly.

\section{Introduction}

Lipases (triacylglycerol acylhydrolase, EC 3.1.1.3) are enzymes capable of catalysing the hydrolysis of long-chain triglycerides to diglycerides, monoglycerides, glycerol and free fatty acids at the oil-water interface (Treichel et al., 2010; Verma et al., 2012). Besides hydrolysis, these enzymes may also catalyse esterification, trans-esterification, inter-esterification, alcoholysis, acidolysis, aminolysis and lactonization reactions (Paques and Macedo, 2006). Lipases are ubiquitous in nature and are produced by several plants, animals and microorganisms. Microbial lipases have gained special industrial attention due to their ability towards extremes of temperature, $\mathrm{pH}$, organic solvents and chemo-, regio- and enantioselectivity. Many microorganisms are known as potential 
producers of extracellular lipases, including bacteria, yeast, and fungi (Messias et al., 2011; Thakur, 2012).

Among microorganisms, yeasts have been used for the production of lipases, due to advantages like wider substrate range, lower sensitivity to low dissolved oxygen concentrations and heavy metals, higher product yield, rapid growth and ease of genetic manipulation (Fickers et al., 2005; Yang, 2011). Finding promising isolated yeasts can open attractive scientific and commercial perspectives. The composition of the culture medium and environmental conditions has an important effect on microorganism metabolism, which is desired to maximize the production of enzymes and reduce costs (Jia et al., 2015). The greatest factor for the expression of lipase activity is the carbon source used in the medium, since these enzymes are produced in the presence of inducers such as oils, triglycerides, fatty acids, hydrolysable esters, glycerol and Tween (Sharma et al., 2001; Gupta et al., 2004). In addition to the carbon source, nitrogen and essential micronutrients should also be carefully evaluated for growth and increased lipase production (Treichel et al., 2010).

Exploration of the biodiversity of lipaseproducing microorganisms with properties suitable for application in various sectors justifies the importance of research and ensures the supply of enzymes, allowing the development of new systems not carried out by enzymes of vegetable or animal origin. The isolation of different strains is the key for discovering novel lipases of interest to industry in general, and in particular of interest to the food industry (Romdhane et al., 2010). Studies indicate the isolation of lipolytic yeasts from various samples, for example, flowers, fruits, soil, leaf surface (Bussamara et al., 2010; Goldbeck and Filho, 2013; Ramesh et al., 2014), butter cheese
(Souza et al., 2015), soybean meal (Smaniotto et al., 2012), wastewater and water samples (Odeyemi et al., 2013), among other sources.

The aims of the present study were to isolate lipolytic yeasts from oily industrial residues, selecting the best strain in relation to lipolytic and esterification activities and to investigate the increase of production in shake flasks.

\section{Materials and Methods}

\section{Isolation and selection of lipase-producing yeasts using tributyrin}

Lipase-producing yeasts were isolated from the residues of crude degummed soybean oil and fish industries located in the city of Rio Grande, Rio Grande do Sul (approximate coordinates, $\left.32^{\circ} 1^{\prime} \mathrm{S} 52^{\circ} 5^{\prime} \mathrm{W}\right)$. The residues were collected at different points from random industrial processes, and transported in coolers to the Bioprocess Engineering Laboratory of the Federal University of Rio Grande (Rio Grande do Sul, Brasil). The residues were codified as: STB - sludge from degumming tanks, CON - condensate obtained in the oil condensation step, DO - degummed oil residue from the tank background, OE - oil residue in tanks exposed to the environment, SM - soybean meal, F - fishmeal, OPF - oil obtained from pressing of fishmeal, RPF residue from the fishmeal pressing tank and FP - fish processing residue.

Subsequently, in order to exhaust the endogenous nutritional resources of the microorganisms, samples were serially diluted with sterile distilled water at $25{ }^{\circ} \mathrm{C}$ for $24 \mathrm{~h}$ and spread onto Petri dishes containing Yeast Malt agar (YM; $1 \%$ glucose, $0.5 \%$ peptone, $0.3 \%$ malt extract, $0.3 \%$ yeast extract and 2 $\%$ agar) (Kumar et al., 2012). The dishes were incubated at $25{ }^{\circ} \mathrm{C}$ for $48 \mathrm{~h}$ in order to isolate individual colonies and test the same for their ability to produce lipase enzymes using 
tributyrin agar (Landell et al., 2010). The lipase-producing yeasts were selected according to the formation of a transparent halo around the colonies when cultivated in Petri dishes containing $0.5 \%$ peptone, $0.3 \%$ yeast extract, $2 \%$ agar and $0.1 \%$ tributyrin at $\mathrm{pH}=6.0$ and incubated at a temperature of 30 ${ }^{\circ} \mathrm{C}$ for $48 \mathrm{~h}$ (Goldbeck and Filho, 2013). After $48 \mathrm{~h}$ of incubation, the colonies with a halo diameter greater than or equal to $20 \mathrm{~mm}$ were selected.

The enzymatic activity index (EAI) is the ratio between the halo diameter and the colony diameter, and classifies the size of halos as small $($ EAI $<2)$, average $($ EAI $=2$ to 5$)$ or large (EAI > 5) (Anagnostakis and Hankin, 1975). The selected strains were maintained on an agar slope (YM), covered with a layer of sterile mineral oil and kept at $4{ }^{\circ} \mathrm{C}$.

\section{Pre-selection of lipase-producing wild yeasts in liquid medium}

The pre-selected yeasts were cultivated in liquid medium containing $5 \%$ peptone, $0.3 \%$ yeast extract, $0.1 \% \mathrm{MgSO}_{4}, 0.1 \% \mathrm{NaNO}_{3}$ and $1 \%$ olive oil at $\mathrm{pH}=6.0$. The inocula were prepared on a GYMP agar slope ( $2 \%$ glucose, $0.5 \%$ yeast extract, $2 \%$ malt extract, $2 \%$ agar and $0.2 \%$ monobasic sodium phosphate) at $30{ }^{\circ} \mathrm{C}$ for $96 \mathrm{~h}$.

After $96 \mathrm{~h}, 10 \mathrm{~mL}$ of liquid medium was added to the agar slope, incubated for $24 \mathrm{~h}$ and transferred to Erlenmeyers containing $45 \mathrm{~mL}$ of medium at a temperature of $30{ }^{\circ} \mathrm{C}$ for $48 \mathrm{~h}$, with agitation at $150 \mathrm{rpm}$ on an orbital shaker. Every $12 \mathrm{~h}$ of cultivation, samples were removed and centrifuged at $3640 \times g$ for 10 $\min$ at $4{ }^{\circ} \mathrm{C}$ and lipolytic activity was determined in the crude enzymatic extract. Esterification activity determination was carried out in the lyophilized crude enzymatic extract after $48 \mathrm{~h}$ of culture (Goldbeck and Filho, 2013).

\section{Different culture media in the production of lipase}

The yeast identified with best lipolytic and esterification activity was cultivated in four media with different compositions: Medium 1 (w/v) $5 \%$ peptone, $1 \%$ soybean oil, $0.1 \%$

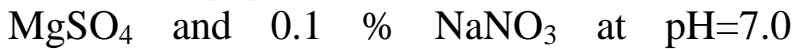
(Maldonado et al., 2012), Medium 2, $1 \%$ soybean oil, $0.2 \%$ yeast extract, $0.05 \%$ $\mathrm{KH}_{2} \mathrm{PO}_{4}, \quad 0.05 \quad \% \quad \mathrm{~K}_{2} \mathrm{HPO}_{4}, \quad 0.05 \%$ $\mathrm{MgSO}_{4} .7 \mathrm{H}_{2} \mathrm{O}, 0.01 \% \mathrm{CaCl}_{2}$ and $0.01 \% \mathrm{NaCl}$ at $\mathrm{pH}=6.0$ (Mafakher et al., 2010), Medium $3,0.5 \%$ yeast extract, $1 \% \mathrm{KH}_{2} \mathrm{PO}_{4}, 0.1 \%$ $\mathrm{MgSO}_{4} .7 \mathrm{H}_{2} \mathrm{O}$ and $1 \%$ olive oil at $\mathrm{pH}=6.8$ (Ramesh et al., 2014) and Medium 4, $5 \%$ peptone, $0.3 \%$ yeast extract, $0.1 \% \mathrm{MgSO}_{4}$, $0.1 \% \mathrm{NaNO}_{3}$ and $1 \%$ olive oil at $\mathrm{pH}=6.0$ (Goldbeck and Filho, 2013). The inocula and cultures were performed as described previously.

The carbon/nitrogen $(\mathrm{C} / \mathrm{N})$ ratio of the different media was estimated using the Solver tool (Excel 2010 software, Microsoft).

\section{Fractional factorial design in the production of lipase}

The effects of the concentration of medium components on lipase production were investigated using the fractional factorial design $2^{5-1}$ with three centre points. The variables and levels studied were peptone ( 2 to $8 \%$ ), yeast extract (0.1 to $0.5 \%), \mathrm{MgSO}_{4}(0$ to $0.2 \%), \mathrm{NaNO}_{3}$ (0 to $0.2 \%$ ) and olive oil $(0.5$ to $1.5 \%)$. The inocula and cultures were performed as described previously.

\section{Determination of lipolytic activity}

Lipolytic activity was measured by titrimetric assay using olive oil as the substrate (Freire $e t$ al., 1997). The reaction mixture consisted of $19 \mathrm{~mL}$ of olive oil/arabic gum emulsion (5\% olive oil and $5 \%$ arabic gum) in $100 \mathrm{mM}$ 
sodium phosphate buffer, $\mathrm{pH}=7.0$. This mixture was homogenized in a blender for 3 min and the enzymatic reaction started by adding $1 \mathrm{~mL}$ of the crude enzymatic extract, incubating for $30 \mathrm{~min}$ at $37^{\circ} \mathrm{C}$. The reaction was stopped by adding $20 \mathrm{~mL}$ of acetoneethanol 1:1 (v/v) and the released fatty acids were titrated with $0.05 \mathrm{M} \mathrm{NaOH}$ solution to $\mathrm{pH}=11.0$. One unit of lipase activity was defined as the amount of enzyme that released $1 \mu \mathrm{mol}$ of fatty acid/min under the described conditions, according to the following Equation 1:

$$
L A=\frac{(V a-V b) * M * 100}{t * V} 1
$$

Where $L A$ is the lipolytic activity $(\mathrm{U} / \mathrm{mL}), V a$ is the volume of $\mathrm{NaOH}$ used for the sample (mL), $V b$ is the volume of $\mathrm{NaOH}$ used for the blank (mL), $M$ is the molarity of the $\mathrm{NaOH}$ solution, $t$ is the reaction time ( $\mathrm{min})$ and $v$ is the volume of enzymatic extract $(\mathrm{mL})$.

\section{Determination of esterification activity}

The esterification activity of lyophilized crude enzymatic extracts was measured by the consumption of acid in the esterification reaction with alcohols (1:1, equimolar ratio) with $100 \mathrm{mg}$ of the enzymatic extract. In all experimental runs, a control assay (blank) was always carried out. After incubation for 40 min at $40{ }^{\circ} \mathrm{C}$ and $160 \mathrm{rpm}$, the fatty acids remaining in the aliquot were extracted by the addition of $20 \mathrm{~mL}$ of an acetone-ethanol solution $(1: 1, \mathrm{v} / \mathrm{v})$. The amount of fatty acids was then titrated with $0.035 \mathrm{M} \mathrm{NaOH}$ solution until $\mathrm{pH}=11.0$. Reaction blanks were run in the same way, but adding the sample after addition of acetone-ethanol solution. A unit of esterification activity was defined as the amount of enzyme that consumes $1 \mu \mathrm{mol} / \mathrm{min}$ of oleic acid per minute under the assay conditions (Langone et al., 2002; Bernardes et al., 2007), according to the following Equation 2:
$E A=\frac{(V a-V b) * N * 1000 * V f}{t * m * V c} 2$

Where $E A$ is the esterification activity (U/g), $V a$ is the volume of $\mathrm{NaOH}$ used for the sample $(\mathrm{mL}), V b$ is the volume of $\mathrm{NaOH}$ used for the blank (mL), $M$ is the molarity of the $\mathrm{NaOH}$ solution, $V f$ is the final reaction volume $(\mathrm{mL})$, $t$ is the time (min), $m$ is the mass of lyophilized enzymatic extract $(\mathrm{g})$ and $V c$ is the volume withdrawn for titration $(\mathrm{mL})$.

\section{Lipolytic productivity}

The lipolytic productivity (U/mL/h) was calculated according to the following Equation 3 (Burkert et al., 2005):

$$
L P=\frac{\operatorname{Max} L A}{t} 3
$$

Where $L P$ is the lipolytic productivity (U/mL/h), Max $L A$ is the maximum lipolytic activity $(\mathrm{U} / \mathrm{mL})$ and $t$ is the corresponding fermentation time.

\section{Determination of cell concentration}

Cell concentration was determined through a gravimetric method, after drying the yeast biomass in $105{ }^{\circ} \mathrm{C}$ until constant mass was reached (Celinska and Grajek, 2013).

\section{Determination of $\mathbf{p H}$}

The $\mathrm{pH}$ of samples was monitored using a digital potentiometer (model MB-10; Marte, São Paulo, Brazil) in accordance with AOAC method no. 972.44 (AOAC, 2000).

\section{Molecular identification}

The microorganisms that showed the best lipolytic and esterification activity were submitted for molecular identification at the Institute of Biological Sciences (Federal University of Minas Gerais, Brasil). 
Firstly, the strain was incubated in malt extract agar at $25{ }^{\circ} \mathrm{C}$ for $24 \mathrm{~h}$. The yeast DNA was extracted and quantified in a Nano Drop ND1000 spectrophotometer (Nano Drop Technologies). The D1/D2 domains of the 26 $S$ subunit were sequenced by using the primers NL1 (5' GCATATCAATAAGC GGAGGAAAAG 3') and NL4 (5' GGTCC GTGTTTCAAGACGG 3'), according to the methodology described by Lachance et al., (1999).

The nucleotide sequence of the amplified D1/D2 fragment was directly sequenced from the purified PCR product. The sequences obtained were compared with sequences deposited at the GenBank database with the BLAST program (GenBank, U.S. National Library of Medicine, Bethesda, MD).

\section{Statistical analysis}

Experiments were conducted in triplicate and the data were statistically analysed using analysis of variance and Tukey's test at $95 \%$ confidence level ( $\mathrm{p}<0.05)$. A statistical analysis related to the estimated effects of each variable was performed at $90 \%$ confidence level $(\mathrm{p}<0.1)$. All statistical analysis was performed with STATISTICA v. 8.0 (StatSoft Inc., Tulsa, OK, USA) software.

\section{Results and Discussion}

\section{Microorganisms isolated in industrial oily residues}

Overall, 78 microorganisms were isolated from industrial oily residues in YM agar. The isolated strains were screened for extracellular lipase using tributyrin agar and 44 were preselected from the formation of a transparent halo around the colonies. In the residue of crude degummed soybean oil 24 microorganisms were isolated, while in the fish residue 20 lipase-producing microorganisms were found (Table 1). The use of supplementary solid media containing emulsified triglycerides is the standard methodology for the selection of lipaseproducing microorganisms, and tributyrin, which indicates the production of lipase by the presence of a transparent zone around the colonies, is often used as the substrate (Cardenas et al., 2001).

After $48 \mathrm{~h}$ of incubation, the agar dishes were analysed according to the production of halos. In this study, of the 44 isolated microorganisms about $4 \%$ showed a large halo (2), $80 \%$ medium (35) and $16 \%$ small (7). The difference in size of the halo can probably be explained either by the amount of extracellular lipase excreted by the microorganism, by the enzyme stability, by the enzyme affinity or by a combination of two or more of these factors (Cardenas et al., 2001).

The highest EAI values were obtained for the microorganisms encoded as OPF1 and DO1, reaching 5.6 and 5.2, respectively. According to Anagnostakis and Hankin (1975), colonies with the highest EAI are those with higher extracellular enzyme activity; however, in this study, this correlation was not observed and the EAI was measured with the sole purpose of classifying the strains isolated from industrial oily residues.

These 44 pre-selected microorganisms were screened for lipase production in liquid medium and strains with the best lipolytic and esterification activity were identified and then the most promising used in a fractional factorial design.

Studies investigating the isolation of lipolytic microorganisms are described in the literature. Goldbeck and Filho (2013) studied lipaseproducing wild yeasts isolated from samples of flowers, fruits and soils from some Brazil 
biomes and obtained 372 strains; 207 showed a hydrolysis halo around the colonies and the EAI of 44 yeasts was classified as large, 86 as medium and 77 as small. Landell et al., (2010) studied the isolation of yeasts from bromeliad leaves and water tank samples and obtained two new strains identified as Candida aechmeae sp. nov. and Candida vrieseae sp. nov. Roveda et al., (2010) isolated 21 lipaseproducing fungi from dairy effluent in submerged fermentation. Thabet et al., (2012) isolated 19 lipolytic yeasts and three bacteria with EAI between 0.4 and 4.5 from an oil waste site collected from a sunflower oil plant.

The initial results of the study and the literature cited suggest that the industrial oily residues studied are good sources for the isolation of lipase-producing microorganisms, and can be found in various habitats, especially those containing lipids.

\section{Cultivation in liquid medium: lipolytic and esterification activity of pre-selected microorganisms}

The lipolytic activity of the 44 pre-selected microorganisms varied from 0.35 to 2.88 $\mathrm{U} / \mathrm{mL}$ while the esterification activity was between 8.08 and $464.65 \mathrm{U} / \mathrm{g}$ (data not presented). Six microorganisms (Table 2) from the fish industry residue stood out for their lipolytic and esterification activities, and were sent for molecular identification.

The microorganism encoded as F1 (Table 2) stood out for its lipolytic $(2.67 \mathrm{U} / \mathrm{mL})$ and esterification (464.65 U/g) activity, significantly higher than the other means, obtained concomitantly at $48 \mathrm{~h}$. The microorganism OPF4 $(2.88 \mathrm{U} / \mathrm{mL})$ showed the maximum lipolytic activity at $12 \mathrm{~h}$ of culture, and there was no statistically significant difference $(p>0.05)$ from $F 1$. The lipolytic productivity of OPF $4\left(0.24 \mathrm{U} / \mathrm{mL}^{\prime} \mathrm{h}\right)$ was statistically higher than others.
During the cultivations a decrease in the production of the enzyme after obtaining maximum lipolytic activity (Fig. 1) could be observed except for the F1 microorganism, which possibly is associated with the release of proteases produced during the cell growth phase (Dalmau et al., 2000). A similar fact was reported by Bussamara et al., (2010) who evidenced the presence of proteases in the medium resulting in a reduction in lipolytic activity after $19 \mathrm{~h}$ of fermentation of lipase from Pseudozyma hubeiensis. The reduction of activity of Candida rugosa lipase by proteases was also observed in a study Puthli et al., (2006). Several studies investigated lipase production and isolation by microorganisms (Table 3). Thus, the lipolytic activity of this study presents lower values when compared to the literature cited, reinforcing the need for viable alternatives, such as factorial design, in order to increase enzymatic activity.

In relation to esterification activity (Table 2) microorganisms coded as OPF5 (346.76 U/g), FP-9 (172.53 U/g), OPF3 (151.91 U/g) and F2 $(110.81 \mathrm{U} / \mathrm{g})$ also showed relevant results. Rigo et al., (2010) obtained lipolytic yeast from soybean meal with catalytic ability for esterification reactions using the same substrate as the study (oleic acid and ethanol). The highest activities were achieved by the yeasts coded $137 \mathrm{Y}$ and $111 \mathrm{Y}$, with $107.94 \mathrm{U} / \mathrm{g}$ and $101.67 \mathrm{U} / \mathrm{g}$, respectively. Reinehr et al., (2014) studied esterification reactions between oleic acid and ethanol (molar ratio 1:1) of lipase from Aspergillus niger and Aspergillus fumigatus isolated from soil contaminated with diesel oil and the activities achieved were 395.43 and $451.5 \mathrm{U} / \mathrm{g}$, respectively, while Ferraz et al., (2012) obtained 189.5 U/g lipase from Sporobolomyces ruberrimus using the same substrate in the reaction. Thus, the esterification activity of the yeasts used in this study was slightly higher than the results reported in the literature. 
Fig.1 Monitoring the lipolytic activity of microorganisms selected and cultivated at $30{ }^{\circ} \mathrm{C}, 48 \mathrm{~h}, 150 \mathrm{rpm}$

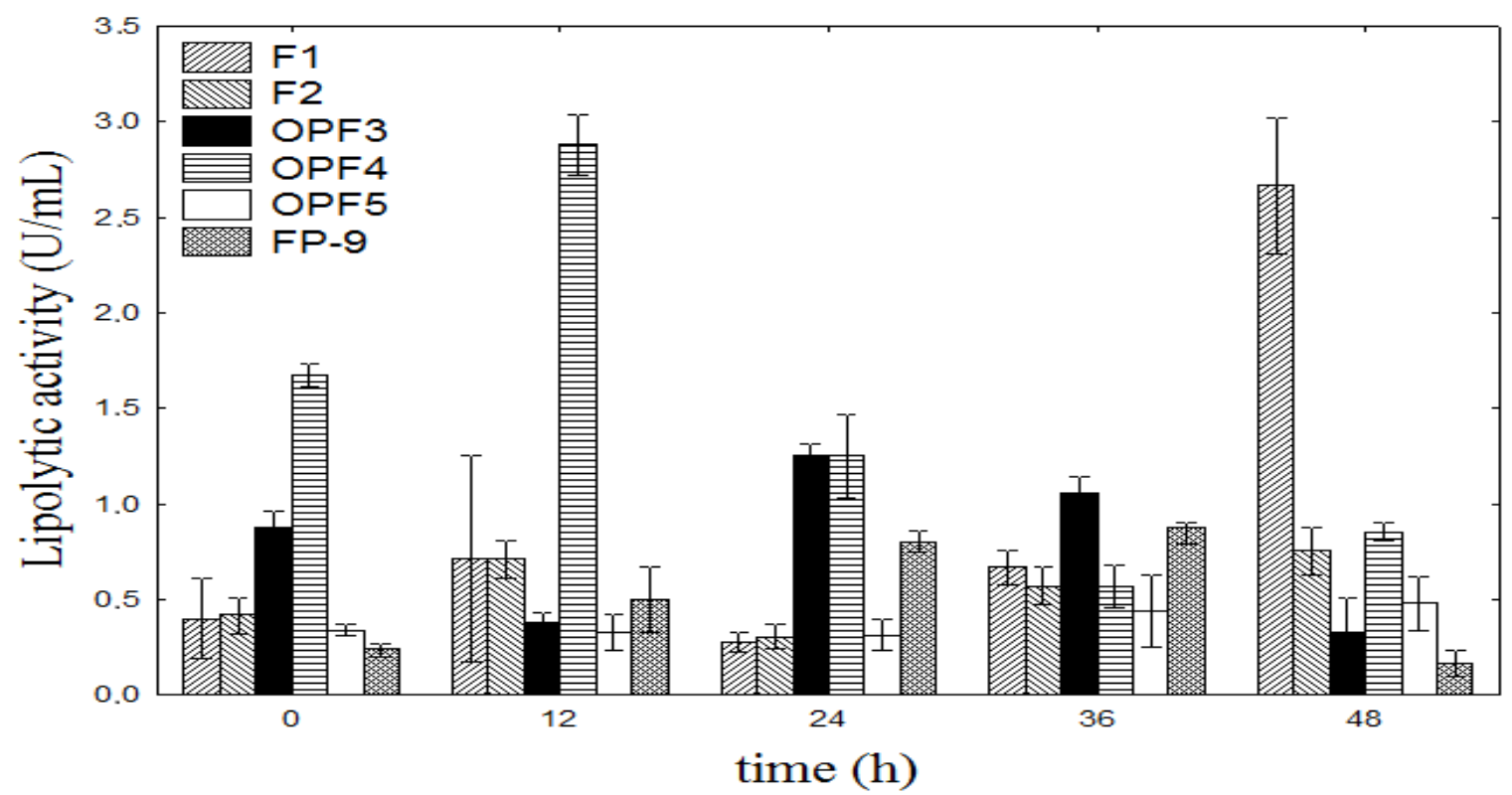

Fig.2 Production of lipase in the four medium culture studied at 48 h cultivation: A) Medium 1, B) Medium 2, C) Medium 3 and D) Medium 4
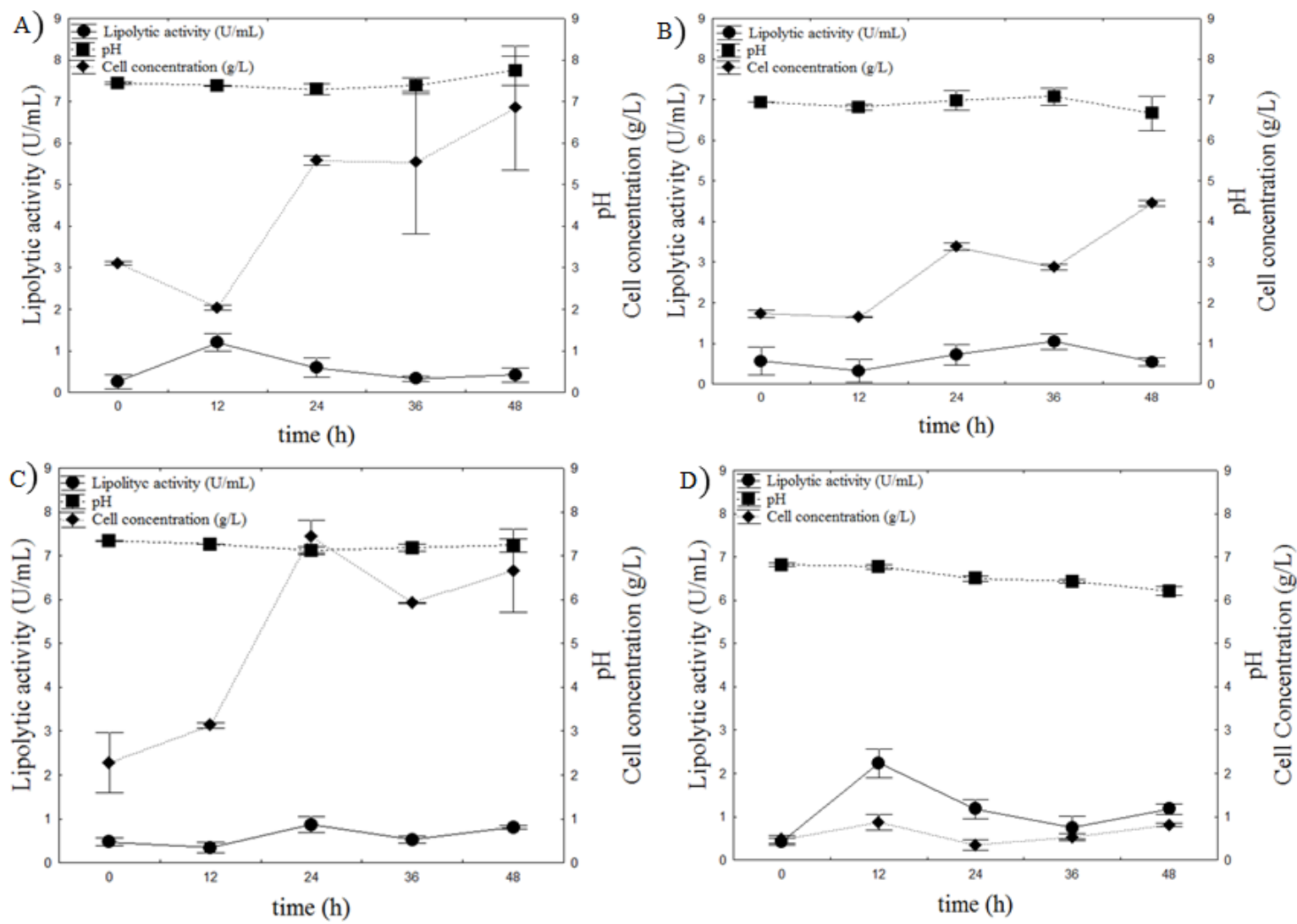
Table.1 Number of microorganisms isolated in YM agar, tributyrin agar and the enzymatic activity index (EAI)

\begin{tabular}{|c|c|c|c|c|}
\hline $\begin{array}{c}\text { Residue } \\
\text { microorganisms }\end{array}$ & $\begin{array}{c}\text { Large } \\
\text { halo }\end{array}$ & $\begin{array}{c}\text { Average } \\
\text { halo }\end{array}$ & $\begin{array}{c}\text { Small } \\
\text { halo }\end{array}$ \\
\hline Crude degummed soybean oil & 24 & 1 & 22 & 1 \\
\hline Fish & 20 & 1 & 13 & 6 \\
\hline
\end{tabular}

Large halo - EAI > 5; average halo - EAI $=2$ to 5; and small halo - EAI $<2$

Table.2 Maximum lipolytic activity (LA, U/mL), production time (h), lipolytic productivity (Lip. prod., $\mathrm{U} / \mathrm{mL}^{\prime} \mathrm{h}$ ) and esterification activity $(\mathrm{EA}, \mathrm{U} / \mathrm{g}$ ) of the six microorganisms selected in residue fish industries

\begin{tabular}{|c|c|c|c|c|}
\hline Code & LA & Time & Lip. prod & EA \\
\hline OPF4 & $2.88 \pm 0.16^{\mathrm{a}}$ & 12 & $0.24 \pm 0.01^{\mathrm{a}}$ & $59.58 \pm 2.79^{\mathrm{e}}$ \\
\hline OPF5 & $0.45 \pm 0.14^{\mathrm{b}}$ & 48 & $0.01 \pm 0.003^{\mathrm{d}}$ & $346.76 \pm 15.60^{\mathrm{b}}$ \\
\hline RPF3 & $2.45 \pm 0.30^{\mathrm{a}}$ & 12 & $0.20 \pm 0.02^{\mathrm{b}}$ & $28.54 \pm 4.73^{\mathrm{e}}$ \\
\hline F1 & $2.67 \pm 0.35^{\mathrm{a}}$ & 48 & $0.06 \pm 0.01^{\mathrm{c}}$ & $464.65 \pm 28.79^{\mathrm{a}}$ \\
\hline F2 & $0.76 \pm 0.12^{\mathrm{b}}$ & 48 & $0.01 \pm 0.003^{\mathrm{d}}$ & $110.81 \pm 7.45^{\mathrm{d}}$ \\
\hline FP-9 & $0.88 \pm 0.09^{\mathrm{b}}$ & 36 & $0.02 \pm 0.003^{\mathrm{d}}$ & $172.53 \pm 29.61^{\mathrm{c}}$ \\
\hline
\end{tabular}

Means \pm SD $(n=3)$ with different superscript letters in the same column indicate that there were significant differences $(\mathrm{p}<0.05)$

Table.3 Studies of literature investigating the production of lipase by wild yeasts with lipolytic activity (LA, U/mL) quantified by titrimetric method

\begin{tabular}{|c|c|c|c|c|}
\hline Strains & Source & Conditions of production & $\mathbf{L A}$ & Ref \\
\hline $\begin{array}{l}\text { Metschnikowia } \\
\text { pulcherrima }\end{array}$ & $\begin{array}{l}\text { Flowers, fruit, and } \\
\text { soil from Brazil } \\
\text { biomes }\end{array}$ & \multirow{7}{*}{$\begin{array}{l}5 \% \text { peptone, } 0.3 \% \text { yeast } \\
\text { extract, } 0.1 \% \text { MgSO }, 0.1 \% \\
\mathrm{NaNO}_{3}, 1 \% \text { olive oil, } 30{ }^{\circ} \mathrm{C} \text {, } \\
150 \mathrm{rpm} \text { and } 48 \mathrm{~h} \\
1 \% \text { olive oil, } 0.2 \% \text { yeast } \\
\text { extract, } 0.05 \% \mathrm{KH}_{2} \mathrm{PO}_{4}, 0.05 \% \\
\mathrm{~K}_{2} \mathrm{HPO}_{4}, 0.05 \% \mathrm{MgSO}_{4} .7 \mathrm{H}_{2} \mathrm{O} \text {, } \\
0.01 \% \mathrm{CaCl}_{2}, 0.01 \% \mathrm{NaCl}, 29 \\
{ }^{\circ} \mathrm{C}, 200 \mathrm{rpm} \text { and } 48 \mathrm{~h} \\
0.5 \% \text { yeast extract, } 1 \% \\
\text { peptone, } 0.4 \% \mathrm{~K}_{2} \mathrm{HPO}_{4}, 0.1 \% \\
\mathrm{MgSO}_{4} .7 \mathrm{H}_{2} \mathrm{O}, 1.31 \% \text { glucose, } \\
1.9 \% \text { olive oil, } 0.38 \% \text { Tween } \\
80,30{ }^{\circ} \mathrm{C}, 150 \mathrm{rpm} \text { and } 72 \mathrm{~h} \\
1 \% \text { glucose, } 3 \% \text { whey powder, } \\
0,8 \%(\mathrm{NH})_{2} \mathrm{SO}_{4}, 1 \% \text { corn } \\
\text { steep liquor, } 0.5 \% \text { olive oil, } 30 \\
{ }^{\circ} \mathrm{C}, 120 \mathrm{rpm} \text { and } 120 \mathrm{~h}\end{array}$} & 4.77 & 1 \\
\hline & & & & \\
\hline $\begin{array}{l}\text { Yarrowia } \\
\text { lipolytica }\end{array}$ & $\begin{array}{l}\text { Agro-industrial } \\
\text { wastewater } \\
\text { treatment plants }\end{array}$ & & 11.0 & 2 \\
\hline & & & & \\
\hline $\begin{array}{l}\text { Debaryomyces } \\
\text { hansenii }\end{array}$ & $\begin{array}{l}\text { Dry-salted olives } \\
\text { of Thassos variety }\end{array}$ & & 7.44 & 3 \\
\hline & & & & \\
\hline Candida boidinii & $\begin{array}{l}\text { Spent olive from } \\
\text { manufacturers of } \\
\text { olive oil }\end{array}$ & & 7.30 & 4 \\
\hline
\end{tabular}

1 - Goldbeck and Filho (2013); 2 - Mafakher et al., (2010); 3 - Papagora et al., (2013); 4 - Bataiche et al., (2014) 
Table.4 Maximum lipolytic activity (LA, U/mL), production time (t, h), lipolytic productivity (Lip. prod., $\mathrm{U} / \mathrm{mL} / \mathrm{h}$ ), cell concentration $(\mathrm{CC}, \mathrm{g} / \mathrm{L}$ ), biomass productivity (Biom. prod., $\mathrm{g} / \mathrm{L} / \mathrm{h}$ ), esterification activity (EA, U/g) and $\mathrm{C}: \mathrm{N}$ ratio in the four culture mediums lipase from Y. lipolytica

\begin{tabular}{|c|c|c|c|c|c|c|c|} 
Med. & LA & $\mathbf{t}$ & $\begin{array}{c}\text { Lip. } \\
\text { prod. }\end{array}$ & CC & $\begin{array}{c}\text { Biom. } \\
\text { prod. }\end{array}$ & EA & C: $\mathbf{N}$ \\
\hline 1 & $1.20 \pm 0.21^{\mathrm{b}}$ & 12 & $0.10 \pm 0.02^{\mathrm{b}}$ & $2.04 \pm 0.06^{\mathrm{b}}$ & $0.17 \pm 0.005^{\mathrm{c}}$ & $47.25 \pm 3.79^{\mathrm{b}}$ & 3.53 \\
\hline $\mathbf{2}$ & $1.05 \pm 0.19^{\mathrm{b}}$ & 36 & $0.03 \pm 0.01^{\mathrm{c}}$ & $2.87 \pm 0.07^{\mathrm{b}}$ & $0.08 \pm 0.002^{\mathrm{c}}$ & $39.74 \pm 1.71^{\mathrm{b}}$ & 14.98 \\
\hline 3 & $0.87 \pm 0.18^{\mathrm{b}}$ & 24 & $0.04 \pm 0.01^{\mathrm{c}}$ & $7.45 \pm 0.37^{\mathrm{a}}$ & $0.31 \pm 0.02^{\mathrm{a}}$ & $34.90 \pm 3.92^{\mathrm{b}}$ & 15.94 \\
\hline 4 & $2.23 \pm 0.33^{\mathrm{a}}$ & 12 & $0.20 \pm 0.19^{\mathrm{a}}$ & $0.93 \pm 0.09^{\mathrm{c}}$ & $0.08 \pm 0.02^{\mathrm{c}}$ & $324.98 \pm 62.29^{\mathrm{a}}$ & 4.04 \\
\hline
\end{tabular}

Med. - Medium; Means $\pm \mathrm{SD}(\mathrm{n}=3)$ with different superscript letters in the same column indicate that there were significant differences $(\mathrm{p}<0.05)$

Table.5 Coded levels and real values (in parentheses) for the $2^{5-1}$ fractional factorial design, lipolytic activity (LA, U/mL), esterification activity $(\mathrm{EA}, \mathrm{U} / \mathrm{g})$ and cell concentration $(\mathrm{CC}, \mathrm{g} / \mathrm{L})$

\begin{tabular}{|c|c|c|c|c|c|c|c|c|}
\hline $\begin{array}{c}\text { Tria } \\
\mathbf{I}\end{array}$ & $\begin{array}{c}\text { Peptone } \\
(\%)\end{array}$ & $\begin{array}{c}\text { Yeast } \\
\text { extract }(\%)\end{array}$ & $\begin{array}{c}\mathrm{MgSO}_{4} \\
(\%)\end{array}$ & $\begin{array}{c}\mathrm{NaNO}_{3} \\
(\%)\end{array}$ & $\begin{array}{c}\text { Olive oil } \\
(\%)\end{array}$ & $\mathrm{LA}$ & EA & $\mathrm{CC}$ \\
\hline $\mathbf{1}$ & $-1(2)$ & $-1(0.1)$ & $-1(0)$ & $-1(0)$ & $+1(1.5)$ & 5.23 & 32.92 & 6.50 \\
\hline $\mathbf{2}$ & $+1(8)$ & $-1(0.1)$ & $-1(0)$ & $-1(0)$ & $-1(0.5)$ & 3.92 & 74.65 & 6.62 \\
\hline $\mathbf{3}$ & $-1(2)$ & $+1(0.5)$ & $-1(0)$ & $-1(0)$ & $-1(0.5)$ & 2.12 & 18.53 & 4.73 \\
\hline $\mathbf{4}$ & $+1(8)$ & $+1(0.5)$ & $-1(0)$ & $-1(0)$ & $+1(1.5)$ & 1.06 & 66.44 & 1.53 \\
\hline $\mathbf{5}$ & $-1(2)$ & $-1(0.1)$ & $+1(0.2)$ & $-1(0)$ & $-1(0.5)$ & 2.24 & 51.08 & 4.92 \\
\hline 6 & $+1(8)$ & $-1(0.1)$ & $+1(0.2)$ & $-1(0)$ & $+1(1.5)$ & 1.28 & 52.58 & 13.30 \\
\hline $\mathbf{7}$ & $-1(2)$ & $+1(0.5)$ & $+1(0.2)$ & $-1(0)$ & $+1(1.5)$ & 1.52 & 11.17 & 3.46 \\
\hline $\mathbf{8}$ & $+1(8)$ & $+1(0.5)$ & $+1(0.2)$ & $-1(0)$ & $-1(0.5)$ & 1.80 & 11.37 & 1.76 \\
\hline $\mathbf{9}$ & $-1(2)$ & $-1(0.1)$ & $-1(0)$ & $+1(0.2)$ & $-1(0.5)$ & 5.12 & 19.74 & 1.80 \\
\hline 10 & $+1(8)$ & $-1(0.1)$ & $-1(0)$ & $+1(0.2)$ & $+1(1.5)$ & 2.61 & 42.65 & 2.52 \\
\hline 11 & $-1(2)$ & $+1(0.5)$ & $-1(0)$ & $+1(0.2)$ & $+1(1.5)$ & 1.03 & 24.58 & 2.40 \\
\hline 12 & $+1(8)$ & $+1(0.5)$ & $-1(0)$ & $+1(0.2)$ & $-1(0.5)$ & 2.45 & 36.04 & 6.52 \\
\hline 13 & $-1(2)$ & $-1(0.1)$ & $+1(0.2)$ & $+1(0.2)$ & $+1(1.5)$ & 0.83 & 86.22 & 1.08 \\
\hline 14 & $+1(8)$ & $-1(0.1)$ & $+1(0.2)$ & $+1(0.2)$ & $-1(0.5)$ & 1.14 & 133.19 & 6.50 \\
\hline 15 & $-1(2)$ & $+1(0.5)$ & $+1(0.2)$ & $+1(0.2)$ & $-1(0.5)$ & 4.32 & 105.22 & 10.30 \\
\hline 16 & $+1(8)$ & $+1(0.5)$ & $+1(0.2)$ & $+1(0.2)$ & $+1(1.5)$ & 0.97 & 42.24 & 11.22 \\
\hline 17 & $0(5)$ & $0(0.3)$ & $0(0.1)$ & $0(0.1)$ & $0(1)$ & 2.99 & 67.51 & 1.66 \\
\hline 18 & $0(5)$ & $0(0.3)$ & $0(0.1)$ & $0(0.1)$ & $0(1)$ & 2.35 & 50.80 & 1.30 \\
\hline 19 & $0(5)$ & $0(0.3)$ & $0(0.1)$ & $0(0.1)$ & $0(1)$ & 2.56 & 57.08 & 1.64 \\
\hline & & & & & & & \\
\hline
\end{tabular}


Table.6 Main effects of the variables on the lipolytic activity, esterification activity and cell concentration of lipase from $Y$. lipolytica

\begin{tabular}{|c|c|c|c|c|c|c|c|c|c|}
\hline & \multicolumn{3}{|c|}{ Lipolytic activity } & \multicolumn{3}{c|}{ Esterification activity } & \multicolumn{3}{c|}{ Cell concentration } \\
\hline $\begin{array}{c}\text { Sources of } \\
\text { variation }\end{array}$ & Effects & Std.Err & $t(13)$ & Effects & Std.Err & $t(13)$ & Effects & Std.Err & $t(13)$ \\
\hline Mean & $2.39^{*}$ & 0.26 & 9.00 & 51.05 & 6.84 & 7.56 & 4.72 & 0.91 & 5.19 \\
\hline \begin{tabular}{c} 
Peptone \\
\hline Yeast
\end{tabular} & -0.89 & 0.58 & -1.54 & 13.71 & 14.92 & 0.91 & 1.84 & 1.98 & 0.93 \\
\hline extract & -0.88 & 0.58 & -1.53 & -22.17 & 14.92 & -1.48 & -0.16 & 1.98 & -0.08 \\
\hline $\mathrm{MgSO}_{4}$ & $-1.18^{*}$ & 0.58 & -2.03 & 22.18 & 14.92 & 1.48 & 2.49 & 1.98 & 1.25 \\
\hline $\mathrm{NaNO}_{3}$ & -0.08 & 0.58 & -0.15 & 21.39 & 14.92 & 1.43 & -0.06 & 1.98 & -0.03 \\
\hline Olive oil $^{2}$ & $-1.07^{*}$ & 0.58 & -1.84 & -11.39 & 14.92 & -0.76 & -0.14 & 1.98 & -0.07 \\
\hline
\end{tabular}

$*$ Significant factors $(p<0.1)$

\section{Identification of microorganism strains}

The molecular identification of the six lipaseproducing microorganisms selected revealed that six yeasts were isolated, by sequencing the D1/D2 domains of the subunit (26 S) ribosomal DNA. As an identification tool, the sequencing of this region is relatively simple to apply and yields clear results (Kurtzman and Robnett, 1997; Leaw et al., 2006). Thus, all yeast isolates were identified as Yarrowia lipolytica and showed $99 \%$ sequence identity with strain NRRL YB-423.

\section{Selection of culture medium for lipase production by $Y$. lipolytica}

Figure 2 shows the lipase production, $\mathrm{pH}$ and cell concentration of the four culture media screened for lipase production by $Y$. lipolytica. Medium 4 showed the highest lipolytic and esterification activities, reaching $2.23 \mathrm{U} / \mathrm{mL}$ (Fig. 2D and Table 4) and 324.98 $\mathrm{U} / \mathrm{g}$, respectively, differing statistically from the other means $(p<0.05)$. In addition to activities, medium 4 also had the highest lipolytic productivity $\left(0.20 \mathrm{U} / \mathrm{mL}^{\prime} \mathrm{h}\right)$ achieved in $12 \mathrm{~h}$ of cultivation. The maximum lipolytic activity of each culture medium was differentiated, occurring at times 12, 36, 24 and $12 \mathrm{~h}$ for media $1,2,3$ and 4 , respectively.
In all culture media, also, there were variations in activity during the cultivations, with a progressive reduction in enzyme activity, which may be due to the secretion of proteases at the end of the logarithmic phase (Dheeman et al., 2010).

The $\mathrm{pH}$ was maintained at about 6.0 to 7.0 , no pronounced changes being observed from the initial pH. According to Iizumi et al., (1990) lipase has a catalytic activity at $\mathrm{pH}=7.0$ and is stable in the $\mathrm{pH}$ range 5.0 to 8.0 , directly influencing the activity, solubility and stability of the enzyme. Benjamin and Pandey (2001) also affirm that neutral pH is generally defined as optimal for lipolytic activity.

Medium 3 showed the highest biomass concentration and, consequently, biomass productivity reached $7.45 \mathrm{~g} / \mathrm{L}$ and $0.31 \mathrm{~g} / \mathrm{L} / \mathrm{h}$ (Table 4), respectively. There were no significant differences between the mean cell concentration of medium $1(2.04 \mathrm{~g} / \mathrm{L})$ and medium 2 (2.87 g/L) ( $\mathrm{p}>0.05)$, while medium 4 showed the lowest growth, at 0.93 $\mathrm{g} / \mathrm{L}$. Thus, the medium with the highest lipolytic activity (medium 4) was not the medium with the highest cell concentration (medium 3); possibly, this is due to the metabolism of the yeast, since productivity and lipase activity are affected by genetic and 
environmental factors (Liu et al., 2015). Another reason for this difference may be related to the growth kinetics of the microorganism and production of the lipase, classifying these processes as non-growthassociated products (Schmidell et al., 2004).

The $\mathrm{C}: \mathrm{N}$ ratio of the four culture media suggests that medium 4, containing two organic nitrogen sources, peptone and yeast extract, exerted a positive influence on lipolytic $(2.23 \mathrm{U} / \mathrm{mL})$ and esterification (324.98 U/g) activity and a negative effect on cell concentration $(0.93 \mathrm{~g} / \mathrm{L})$. According to Lima et al., (2001) a suitable C: $\mathrm{N}$ balance can be critical, especially if the $\mathrm{pH}$ is not controlled. Thus, as noted previously also in medium 3, production of the enzyme was not associated with cell growth (Schmidell et al., 2004).

Thus, medium 4 was selected for the continuity of the work, due to higher lipolytic and esterification activity achieved together, aiming to increase the production of extracellular lipase of $Y$. lipolytica.

\section{Effect of culture medium composition on lipase production}

The effect of medium composition on the production of lipase by $Y$. lipolytica was evaluated by varying the concentrations of the components in medium 4. The lipolytic activity ranged from 0.83 (trial 13) to 5.23 $\mathrm{U} / \mathrm{mL}$ (trial 1), esterification activity from 11.17 (trial 7) to $133.19 \mathrm{U} / \mathrm{g}$ (trial 14) and cell concentration from 1.08 (trial 13 ) to $13.30 \mathrm{~g} / \mathrm{L}$ (trial 6) (Table 5).

The maximum lipolytic activity of trial 1 $(5.23 \mathrm{U} / \mathrm{mL}$ in $36 \mathrm{~h})$ and trial $9(5.12 \mathrm{U} / \mathrm{mL}$ in $12 \mathrm{~h}$ ) was obtained in culture media with lower concentrations of peptone, yeast extract and $\mathrm{MgSO} 4$. The activities obtained increased about $50 \%$ compared with the activity of medium 4 (2.23 U/mL, Table 4) and also in the central points, varying from $2.35 \mathrm{U} / \mathrm{mL}$ (trial 17) to $2.99 \mathrm{U} / \mathrm{mL}$ (trial 19). Lower concentrations of constituents contribute to a cost reduction in the production of lipase by $Y$. lipolytica.

Trials 14 (133.19 U/g) and 15 (105.22 U/g) in the fractional factorial design showed the highest esterification activities and the culture medium contained a low concentration of olive oil and high concentrations of $\mathrm{NaNO}_{3}$ and $\mathrm{MgSO}_{4}$. However, comparing these trials with medium 4 (324.98 U/g, Table 4) there was a reduction in esterification activity of approximately $60 \%$, which may be related to the low concentration of olive oil $(0.5 \%)$ as it has proved to be an efficient inducer for lipase production at a concentration of $1 \%$ $(w / v)$. Despite the reduction in esterification activity, trial 15, composed of $2 \%$ peptone, $0.5 \%$ yeast extract, $0.2 \% \mathrm{MgSO}_{4}, 0.2 \%$ $\mathrm{NaNO}_{3}$ and $0.5 \%$ olive oil, showed relevant lipolytic activity $(4.32 \mathrm{U} / \mathrm{mL})$ and cell concentration $\quad(10.30 \mathrm{~g} / \mathrm{L}), \quad$ achieved concomitantly. In relation to cell concentration, trial 6 , constituted by $8 \%$ peptone, $0.1 \%$ yeast extract, $0.2 \% \mathrm{MgSO}_{4}$ and $1.5 \%$ olive oil, obtained the highest concentration with $13.30 \mathrm{~g} / \mathrm{L}$. This culture medium presented the highest levels of peptone, $\mathrm{MgSO}_{4}$ and olive oil.

The estimated effect for each variable was determined (Table 6 ) for $48 \mathrm{~h}$ of fermentation. An estimate of the main effects can be obtained by evaluating the difference in process performance caused by changing from a low $(-1)$ to high $(+1)$ level of the corresponding factor (Rodrigues and Iemma, 2009). The increase in concentration of $\mathrm{MgSO}_{4}$ and olive oil exerted negative significant effects $(\mathrm{p}<0.1)$ on lipolytic activity, decreasing the activity to 1.18 and $1.07 \mathrm{U} / \mathrm{mL}$, respectively. In the fractional factorial design for the five factors studied the 
effects were not statistically significant for esterification activity and cell concentration in the range analysed $(p>0.1)$. Thus, the variables that significantly influenced the production of lipase by $Y$. lipolytica were $\mathrm{MgSO}_{4}$ and olive oil. Ramani et al., (2010) studied the production of lipase by Pseudomonas gessardii and observed that by adding $0.1 \%$ (w/v) $\mathrm{MgSO}_{4}$ to the medium, there was also a reduction in enzyme activity.

A total of 78 microorganisms were isolated from industrial oily residues and only six strains were selected due to considerable lipolytic and esterification activities in liquid medium. The yeast identified as $Y$. lipolytica was the most promising with higher lipolytic $(2.67 \mathrm{U} / \mathrm{mL})$ and esterification $(464.65 \mathrm{U} / \mathrm{g}$ ) activity obtained in conjunction. In the maximization of lipase production, medium 4 showed the best results, indicating in the factorial design that an increase in the concentration of $\mathrm{MgSO}_{4}$ and olive oil variables was significant in lipolytic activity, causing a decrease in its value. The search for new sources for isolating lipase-producing microorganisms, in particular by yeast, is important to find out more stable and selective enzymes applicable in many processes.

\section{Acknowledgments}

We are grateful to $\mathrm{CNPq}, \mathrm{CAPES}$ and FAPERGS for the financial support of this work and scholarships. We acknowledge the $\mathrm{PhD}$ Carlos Augusto Rosa of the Microbiology Department, Federal University of Minas Gerais, by molecular identification of the yeast studied.

\section{References}

Anagnostakis, S.L., and Hankin L. 1975. Use of selective media to detect enzyme production by microorganisms in food products. J Milk Food Technol. 38(10):570-572.

AOAC Official Method 972.44. 2000. Microbiological Method. Washington: Association of Official Analytical Chemists.

Bataiche, I., Kacem-Chaouche, N., Destain, J., Lejeune, A., and Thonart, P. 2014. Screening of Candida boidinii from Chemlal spent olive characterized by higher alkaline-cold adapted lipase production. Afr J Biotechnol. 13(11):1287-1294.

Benjamin, S., and Pandey, A. 2001. Isolation and characterization of three distinct forms of lipases from Candida rugosa produced in solid state fermentation. Braz Arch Biol Technol. 44(2):453-460.

Bernardes, O.L., Bevilaqua, J.V., Leal, M.C.M.R., Freire, D.M.G., and Langone, M.A.P. 2007. Biodiesel fuel production by the transesterification reaction of soybean oil using immobilized lipase. Appl Biochem Biotechnol. 136(140):105-114.

Burkert, J.F.M., Maldonado, R.R., Maugeri, F., and Rodrigues, M.I. 2005. Comparison of lipase production by Geotrichum candidum in stirring and airlift fermenters. J Chem Technol Biotechnol. 80:61-67.

Bussamara, R., Fuentefria, A.M., Oliveira, E.S., Broetto, L., Simcikova, M., Valente, P., Schrank, A., and Vainstein, M.H. 2010. Isolation of a lipasesecreting yeast for enzyme production in a pilot-plant scale batch fermentation. Bioresour. Technol. 101(1):268-275.

Cardenas, F., Alvarez, E., Castro-Alvarez, M.S., Sanchez-Montero, J.M., Valmaseda, M., Elson, S.W., and Sinisterra, J.V. 2001. Screening and catalytic activity in organic synthesis of novel fungal and yeast lipases. $\mathrm{J}$ Mol Catal B: Enzym. 14(6):111-123.

Celinska, E., and Grajek, W. 2013. A novel 
multigene expression construct for modification of glycerol metabolism in Yarrowia lipolytica. Microb Cell Fact. 12(102):1-16.

Dalmau, E., Montesinos, J.L., Lotti, M., and Casas, C. 2000. Effect of different carbon sources on lipase production by Candida rugosa. Enzyme Microb Technol. 26:657-663.

Dheeman, D.S., Frias, J.M., and Henehan G.T.M. 2010. Influence of cultivation conditions on the production of thermostable extracellular lipase from Amycolatopsis mediterranei DSM 43304. J Ind Microbiol Biotechnol. 37(1):1-17.

Ferraz, L.R., Oliveira, D.S., Silva, M.F., Rigo, E., Di Luccio, M., Oliveira, J.V., Oliveira, D., and Treichel, H. 2012. Production and partial characterization of multifunctional lipases by Sporobolomyces ruberrimus using soybean meal, rice meal and sugarcane bagasse as substrates. Biocatal Agric Biotechnol. 1(3):243-252.

Fickers, P., Fudalej, F., Le Dall, M.T., Casaregola, S., Gaillardin, C., Thonart, P., and Nicaud, J.M. 2005. Identification and characterisation of LIP7 and LIP8 genes encoding two extracellular triacylglycerol lipases in the yeast Yarrowia lipolytica. Fungal Genet Biol. 42(3):264-274.

Freire, D.M., Teles, E.M.F., Bon, E.P.S., and Lippel, G.S. 1997. Lipase production by Penicillium restrictum in a batch-scale fermenter: effect of carbon and nitrogen nutrition, agitation and aeration. Appl Biochem Biotechnol. 63(1): 409-421.

Goldbeck, R., Filho, F.M. 2013. Screening, characterization, and biocatalytic capacity of lipases producing wild yeasts from Brazil biomes. Food Sci Biotechnol. 22:79-87.

Gupta, R., Gupta, N., and Rathi, P. 2004. Bacterial lipases: An overview of production, purification and biochemical properties. Appl Microbiol Biotechnol. 64(6):763-781.

Iizumi, T., Nakamuraa, K., and Fukase, T. 1990. Purification and characterization of a thermostable lipase from newly isolated Pseudomonas sp. KWI-56. Agric Biol Chem. 54(5):1253-1258.

Jia, J., Yang, X., Wu, Z., Zhang, Q., Lin, Z., Guo, H., Lin, C.S.K., Wang, J., and Wang, Y. 2015. Optimization of fermentation medium for extracellular lipase production from Aspergillus niger using response surface methodology. BioMed Res Int. 2015:18.

Kumar, A., Surendra, S.P., and Nisha, B. 2012. Enrichment, isolation and optimization of lipase-producing Staphylococcus sp. from oil mill waste (Oil cake). J Exp Sci. 3(8):26-30.

Kurtzman, C.P., and Robnett, C.J. 1997. Identification of clinically important ascomycetous yeasts based on nucleotide divergence in the 5 ' end of the large-subunit (26S) ribosomal DNA gene. J Clin Microbiol. 35(5):12161223.

Lachance, M.A., Bowles, J.M., Starmer, W.T., and Barker, J.S.F. 1999. Kodamaea kakaduensis and Candida tolerans, two new yeast species from Australian Hibiscus flowers. Can J Microbiol. 45(2):172-177.

Landell, M.F., Billodre, R., Ramos, J.P., Leoncini, O., Vainstein, M.H., and Valente, P. 2010. Candida aechmeae sp. nov. and Candida vrieseae sp. nov., novel yeast species isolated from the phylloplane of bromeliads in Southern Brazil. Int J Syst Evol Microbiol. 60:244-248.

Langone, M.A., Abreu, M.E., Rezende, M.J., and Sant'anna, G.L. 2002. Enzymatic synthesis of medium chain monoglycerides in a solvent-free 
system. Appl Biochem Biotechnol. 100:987-996.

Leaw, S.N., Chang, H.C., Sun, H.F., Barton, R., Bouchara, J.P., and Chang, T.C. 2006. Identification of medically important yeast species by sequence analysis of the internal transcribed spacer regions. J Clin Microbiol. 44(3):693-699.

Lima, U.D.A., Aquarone, E., Borzani, W., and Schmidell, W. 2001. Biotecnologia industrial: processos fermentativos e enzimáticos. In: Edgard Blücher (Ed.), vol. $3,616 \mathrm{p}$.

Liu, H.H., Ji, X.J., and Huang, H. 2015. Biotechnological applications of Yarrowia lipolytica: Past, present and future. Biotechnol Adv. 33(8):15221546.

Mafakher, L., Mirbagheri, M., Darvishi, F., Nahvi, I., Zarkesh-Esfahani, H., and Emtiazi, G. 2010. Isolation of lipase and citric acid producing yeasts from agroindustrial wastewater. $\mathrm{N}$ Biotechnol. 27(4):337-340.

Maldonado, R.R., Panciera, A.L., Macedo, G.A., Mazutti, M.A., Filho, F.M., Rodrigues, M.I. 2012. Improvement of lipase production from Geotrichum sp. in shaken flasks. Chem Ind Chem Eng Q. 18(3):459-464.

Messias, J.M., Costa, B.Z., Lima, V.M.G., Giese, E.C., Dekker, R.F.H., and Barbosa, A.M. 2011. Microbial lipases: production, properties and biotechnological applications. Semina: Ciências Exatas e Tecnológicas. 32(2):213-234.

Odeyemi, A.T., Aderiye, B.I., and Bamidele, O.S. 2013. Lipolytic activity of some strains of Klebsiella, Pseudomonas and Staphylococcus spp. from restaurant wastewater and receiving stream. J Microbiol Res. 3(1):43-52.

Papagora, C., Roukas, T., and Kotzekidou, P. 2013. Optimization of extracellular lipase production by Debaryomyces hansenii isolates from dry-salted olives using response surface methodology. Food Bioprod Process. 91(4):413-420.

Paques, F.W., and Macedo, G.A. 2006. Plant lipase from latex: properties and industrial applications. Quím Nova. 29(1):93-99.

Puthli, M.S., Rathod, V.K., and Pandit, A.B. 2006. Optimization of lipase production in a triple impeller bioreactor. Biochem Eng J. 27(3):287-294.

Ramani, K., Kennedy, L.J., Ramakrishnana, M., and Sekarana, G. 2010. Purification, characterization and application of acidic lipase from Pseudomonas gessardii using beef tallow as a substrate for fats and oil hydrolysis. Process Biochem. 45(10):531-535

Ramesh, S., Kumar, R., Devi, R.A., and Balakrishnan, K. 2014. Isolation of a lipase producing bacteria for enzyme synthesis in shake flask cultivation. Int $\mathbf{J}$ Curr Microbiol Appl Sci. 3(3):712-719.

Reinehr, C.O., Rizzradi, J., Silva, M.F., Oliveira, D., Treichel, H., and Colla, M.L. 2014. Production of lipases with Aspergillus niger and Aspergillus fumigatus through solid state fermentation: evaluation of substrate specificity and use in esterification and alcoholysis reactions. Quim Nova. 37(3):454-460.

Rigo, E., Polloni, A.E., Remonatto, D., Arbter, F., Menoncin, S., Oliveira, V., Treichel, H., Kalil, S.J., Ninow, J.L., and Di Luccio, M. 2010. Esterification activity of novel fungal and yeast lipases. Appl Biochem Biotechnol. 162: 1881-1888.

Rodrigues, M.I., and Iemma, A.F. 2009. Planejamento de experimentos e otimização de processos. In: Casa do Pão Editora (Ed.), 326p.

Romdhane, I.B., Fendri, A., Gargouri, Y., Gargouri, A., and Belghith, H. 2010. A 
novel thermoactive and alkaline lipase from Talaromyces thermophiles fungus for use in laundry detergents. Biochem Eng J. 53(1):112-120.

Roveda, M., Hemkemeier, M., and Colla, L.M. 2010. Evaluation of lipase production using different strains of microorganisms isolated from dairy effluent through submerged fermentation. Food Sci Technol. JanMar; 30(1):126-131.

Schmidell, W., Lima, U.A., Aquarone, E., and Borzani, W. 2004. Biotecnologia Industrial-Engenharia Bioquímica. In: Edgard Blücher (Ed.), vol. 1, 541p.

Sharma, R., Chisti, Y., and Banerjee, U.C. 2001. Production, purification, characterization, and applications of lipase. Biotechnol Adv. 19(8):627-662.

Smaniotto, A., Skovronski, A., Rigo, E., Tsai, S.M., Durrer, A., Foltran, L.L., Di Luccio, M., Oliveira, J.V., Oliveira, D., and Treichel, H. 2012. Synthetic lipase production from a newly isolated Sporidiobolus pararoseus strain by submerged fermentation. Braz J Microbiol. 43(4):1490-1498.

Souza, L.T.A., Oliveira, J.S., Rodrigues, M.Q.R.B., Santos, V.L., Pessela, B.C., and Resende, R.R. 2015. Macaúba
(Acrocomia aculeata) cake from biodiesel processing: a low-cost substrate to produce lipases from Moniliella spathulata R25L270 with potential application in the oleochemical industry. Microb Cell Fact. 14(87):1-14.

Thabet, H.M., Pasha, A.C., Ahmed, M.M., and Linga, V. 2012. Isolation of novel lipase producing Sporobolomyces salmonicolor OVS8 from oil mill spillage and enhancement of lipase production. Jord. J. Biol. Sci. 5(4): 301306.

Thakur, S. 2012. Lipases, its sources, properties and applications: a review. Int J Sci Eng Res. 3(7):1-29.

Treichel, H., Oliveira, D., Mazutti, M.A., Di Luccio, M., and Oliveira, V.J. 2010. A review on microbial lipases production. Food Bioproc Tech. 3:182-196.

Verma, N., Thakur, S., and Bhatt, A.K. 2012. Microbial lipases: industrial applications and properties (A Review). Int Res J Biol Sci. 1(8):88-92.

Yang, S.T. 2011. Bioprocessing for valueadded products from renewable resources: new technologies and applications. In: Elsevier.

\section{How to cite this article:}

Michele Putti Paludo, Kelly Silva Degani de Oliveira, Thalles Canton Trevisol and Janaina Fernandes de Medeiros Burkert. 2018. Isolation of Lipase-Producing Yeasts from Industrial Oily Residues in Different Culture Media. Int.J.Curr.Microbiol.App.Sci. 7(01): 2348-2362. doi: https://doi.org/10.20546/ijcmas.2018.701.283 